University of Nebraska - Lincoln

DigitalCommons@University of Nebraska - Lincoln

September 2007

\title{
Soil carbon and tree litter dynamics in a red cedar-scotch pine shelterbelt
}

Thomas J. Sauer

USDA-ARS

Cynthia A. Cambardella

USDA-ARS

James R. Brandle

University of Nebraska - Lincoln, jbrandle1@unl.edu

Follow this and additional works at: https://digitalcommons.unl.edu/natrespapers

Part of the Natural Resources and Conservation Commons

Sauer, Thomas J.; Cambardella, Cynthia A.; and Brandle, James R., "Soil carbon and tree litter dynamics in a red cedar-scotch pine shelterbelt" (2007). Papers in Natural Resources. 107.

https://digitalcommons.unl.edu/natrespapers/107

This Article is brought to you for free and open access by the Natural Resources, School of at DigitalCommons@University of Nebraska - Lincoln. It has been accepted for inclusion in Papers in Natural Resources by an authorized administrator of DigitalCommons@University of Nebraska - Lincoln. 


\title{
Soil carbon and tree litter dynamics in a red cedar-scotch pine shelterbelt
}

\author{
Thomas J. Sauer · Cynthia A. Cambardella • \\ James R. Brandle
}

Received: 20 April 2006/Accepted: 16 May 2007/Published online: 7 June 2007

\begin{abstract}
Carbon sequestration in the woody biomass of shelterbelts has been investigated but there have been no measurements of the $\mathrm{C}$ stocks in soil and tree litter under this agroforestry practice. The objective of this study was to quantify C stored in surface soil layers and tree litter within and adjacent to a 35-year-old shelterbelt in eastern Nebraska, USA. The 2-row shelterbelt was composed of eastern red cedar (Juniperus virginiana) and scotch pine (Pinus sylvestris). A sampling grid was established across a section of the shelterbelt on Tomek silt loam (fine, smectitic, mesic Pachic Argiudolls). Four soil cores were collected at each grid point, divided into $0-7.5$ and $7.5-15 \mathrm{~cm}$ depth increments, and composited by depth. Soil samples were analyzed for total, organic, and inorganic $\mathrm{C}$, total $\mathrm{N}$, texture, $\mathrm{pH}$, and nutrient content. Under the shelterbelt, all surface litter in a $0.5 \times 0.5 \mathrm{~m}^{2}$ area at each grid point was collected prior to soil sampling, dried, weighed, sorted, and analyzed for total C and N. Average soil
\end{abstract}

The U.S. Government's right to retain a non-exclusive, royaltyfree license in and to any copyright is acknowledged.

T. J. Sauer $(\bowtie) \cdot$ C. A. Cambardella USDA-ARS, National Soil Tilth Laboratory, 2150

Pammel Drive, Ames, IA 50011-3120, USA

e-mail: sauer@nstl.gov

J. R. Brandle

School of Natural Resources, University of NebraskaLincoln, Lincoln, NE 68583-0974, USA organic carbon (SOC) in the $0-15 \mathrm{~cm}$ layer within the shelterbelt $\left(3,994 \mathrm{~g} \mathrm{~m}^{-2}\right)$ was significantly greater than in the cultivated fields $\left(3,623 \mathrm{~g} \mathrm{~m}^{-2}\right)$. The tree litter contained an additional $\sim 1,300 \mathrm{~g} \mathrm{C} \mathrm{m}^{-2}$. Patterns of litter mass and soil $\mathrm{pH}$ and texture suggested increased organic inputs by tree litter and deposition of wind-blown sediment may be responsible for greater SOC beneath the shelterbelt. Further research is needed to identify the mechanism(s) responsible for the observed patterns of SOC within and adjacent to the shelterbelt and to quantify the $\mathrm{C}$ in biomass and deeper soil layers.

Keywords Soil organic carbon - Tree litter .

Shelterbelt $\cdot$ Red cedar $\cdot$ Scotch pine

Carbon (C) sequestration in woody biomass is promoted as a practice to offset increasing atmospheric carbon dioxide $\left(\mathrm{CO}_{2}\right)$ concentrations. Extensive analyses of forest productivity for various forest types and management practices have been completed to quantify their potential for $\mathrm{C}$ sequestration (Vitousek 1991; Harmon 2001; Kirschbaum 2003). These analyses concern estimates of $\mathrm{C}$ sequestration primarily in above-ground biomass. Paul et al. (2002) reviewed global data on changes in soil $\mathrm{C}$ following afforestation and found that, on average, soil $\mathrm{C}$ decreased during the first 5 years of afforestation but generally recovered to $\mathrm{C}$ contents comparable to agricultural soils by 30 years. The data were highly 
variable and included both net increasing and net decreasing soil $\mathrm{C}$ content. The most important factors affecting changes in soil $\mathrm{C}$ were previous land use, climate, and forest type. Deciduous hardwoods or $\mathrm{N}_{2-}$ fixing species established on formerly cropped land in tropical or subtropical regions tended to produce the greatest soil $\mathrm{C}$ accumulation. Davis and Condron (2002), Paul et al. (2002), and Vesterdal et al. (2002) each noted that decreasing $\mathrm{C}$ in the surface soil layer after afforestation was partially offset by $\mathrm{C}$ accumulation in tree litter on the forest floor.

A shelterbelt or field windbreak is an agroforestry practice that consists of one or more rows of trees planted across crop fields or grazing lands to reduce wind speed and enhance the local microclimate for crop and animal production. Shelterbelts are most common in semiarid areas where they also protect the soil from wind erosion. The largest shelterbeltplanting program in the U.S. was the Prairie States Forestry Project that planted nearly $30,000 \mathrm{~km}$ of shelterbelts in six Great Plains states between 1935 and 1942 (Droze 1977). Brandle et al. (1992), Schroeder (1994), and Kort and Turnock (1999) estimated $\mathrm{C}$ sequestration in above-ground biomass for different shelterbelt types in the U.S. and Canada. These estimates ranged from $<1 \mathrm{Mg} \mathrm{C} \mathrm{km}^{-1}$ for single-row shrubs to $>100 \mathrm{Mg} \mathrm{C} \mathrm{km}^{-1}$ of hybrid poplar (Populus $\times$ deltoides). None of these assessments considered the tree litter, below-ground biomass, or soil $\mathrm{C}$ sequestration potential of shelterbelts.

Planting trees on soils previously managed for crop or forage production has potential to significantly alter soil properties through fundamental changes in organic matter and nutrient cycling processes. In forest systems, litter-fall on the soil surface is the primary organic input, whereas in many cropping and grassland systems the primary organic input is the decomposition of roots (Pettapiece 1969; Anderson 1987; Gale and Cambardella 2000). Decomposition of tree litter on the soil surface in forests tends to occur rapidly and, in the absence of mineral colloids, results in few stabilizing clayhumus complexes. Forest soils are often characterized by a thin, organic-rich $\mathrm{O}$ horizon over an $\mathrm{A}$ horizon and deeper horizons having relatively low concentrations of clay and nutrients with significant losses of soluble organic N, S, and P components and cations ( $\mathrm{Ca}, \mathrm{Mg}$ and $\mathrm{K}$ ) due to leaching (Anderson 1987).
Nair and Nair (2003) recommended that, to fully assess the $\mathrm{C}$ sequestration potential of agroforestry systems, C stock estimates should include forest products, detritus (tree litter), and soil components. Since the 1930s, shelterbelts have been planted extensively in the Great Plains of the U.S. Accurate assessment of the $\mathrm{C}$ stocks of existing and potential shelterbelt plantings is needed to determine the full capacity of this agroforestry practice to sequester C. The objective of this study was to quantify the $\mathrm{C}$ stored in surface soil layers and in tree litter within and adjacent to a 35-year-old shelterbelt in eastern Nebraska.

\section{Materials and methods}

The study site was located at the University of Nebraska-Lincoln Agricultural Research and Development Center near Mead, NE ( $41^{\circ} 9^{\prime} \mathrm{N}, 9^{\circ} 29^{\prime} \mathrm{W}$, $356 \mathrm{~m}$ asl). The soils at this location formed on a loess-mantle over an ancient terrace of the Platte River. In the fall of 2003, a section of a shelterbelt located on Tomek silt loam (fine, smectitic, mesic Pachic Argiudolls) was selected for sampling. The shelterbelt was planted in 1968, had a north-south orientation, and consisted of two rows of three tree species (eastern red cedar (Juniperus virginiana), scotch pine (Pinus sylvestris), and eastern cottonwood (Populus deltoides)). The tree rows were $400 \mathrm{~m}$ long and spaced $3.65 \mathrm{~m}$ apart with $1.8 \mathrm{~m}$ between trees within rows. The original cottonwood trees were removed after $\sim 15$ years although some trees grown from their seed were present in 2003. At the time of sample collection, the scotch pine and red cedar trees were approximately $8 \mathrm{~m}$ tall and $0.25 \mathrm{~m}$ in diameter (DBH). Red mulberry (Morus rubra), honeylocust (Gleditsia triacanthos) and various grasses and forbs had invaded the margins of the shelterbelt. Cropping histories of the adjacent fields were available for growing seasons after 1974. The fields were cropped primarily to soybean [Glycine $\max (\mathrm{L}$.) Merr.], wheat (Triticum aestivum), and grain sorghum or milo [Sorghum bicolor (L.) Moench] (Table 1).

A sampling grid $(7 \times 17$ parallel-to $\times$ perpendicular-to shelterbelt) was established at a $1.8-\mathrm{m}$ spacing except for the two columns of points between the tree rows. These two columns were only $1.2 \mathrm{~m}$ apart to allow better representation and greater separation 
Table 1 Management history from 1975 to 2003 for cultivated fields west and east of the Mead shelterbelt

\begin{tabular}{|c|c|c|c|c|}
\hline $\begin{array}{l}\text { Time } \\
\text { period }\end{array}$ & West field crops & $\begin{array}{l}\text { West field } \\
\text { fertility }\end{array}$ & East field crops & $\begin{array}{l}\text { East field } \\
\text { fertility }\end{array}$ \\
\hline 1995-2003 & $\begin{array}{l}\text { corn (2), wheat (1), soybean (1); soybean (1), } \\
\text { wheat (1), oats (1), sunflower (1), milo (1) }\end{array}$ & $\begin{array}{l}\text { manure (4), } N \\
\text { fertilizer (1), } \\
\text { lime (1) }\end{array}$ & $\begin{array}{l}\text { soybean }(5), \text { wheat }(1), \text { milo }(1), \\
\quad \text { sunflower }(1), \text { corn }(1)\end{array}$ & $\begin{array}{l}\mathrm{N} \text { fertilizer (5), } \\
\quad \text { lime (1) }\end{array}$ \\
\hline 1985-1994 & soybean (5), wheat (3), milo (2) & $\mathrm{N}$ fertilizer $(3)$ & soybean (5), wheat (3), milo (2) & $\begin{array}{l}\mathrm{N} \text { fertilizer (5), } \\
\text { lime (2) }\end{array}$ \\
\hline 1975-1984 & milo (6), wheat (4) & & milo (5), wheat (4), soybean (1) & \\
\hline Total & $\begin{array}{l}\text { milo }(9) \text {, wheat }(9) \text {, soybean }(7) \text {, corn }(2) \text {, } \\
\text { sunflower }(1) \text {, oats }(1)\end{array}$ & $\begin{array}{l}\text { manure (4), N } \\
\text { fertilizer (4), } \\
\text { lime (1) }\end{array}$ & $\begin{array}{l}\text { soybean }(11) \text {, milo }(8), \text { wheat } \\
(8), \text { sunflower }(1) \text {, corn }(1)\end{array}$ & $\begin{array}{l}\mathrm{N} \text { fertilizer } \\
\quad(10), \text { lime (2) }\end{array}$ \\
\hline
\end{tabular}

Values in parentheses are number of years in each crop and number of applications for manure, fertilizer, and lime. Crops in italics were grown under organic cultural practices

between these sample points and the tree rows. Prior to soil sampling, aboveground tree litter was collected from a $0.5 \times 0.5 \mathrm{~m}^{2}$ area centered on each grid point within the shelterbelt $(n=62)$. Samples were placed in plastic bags, transferred to paper bags, dried at $55^{\circ} \mathrm{C}$ for $48 \mathrm{~h}$, weighed, and sorted into litter classes. Eight of the 10 litter classes (sticks, pine needles, pine cones/juniper seeds, deciduous leaves, annuals, corn residue, worm casts, and insect carapaces) were sorted by visual identification. Remaining litter was separated into coarse duff ( $>2 \mathrm{~mm}$-diam.) and fine duff ( $<2 \mathrm{~mm}$-diam.) using a $2-\mathrm{mm}$ sieve. Samples of each litter class were ground in a Wiley mill $^{1}$ (Model 4, Thomas Scientific, Swedesboro, NJ) and a subsample was placed on a roller mill (Bailey Mfg., Inc., Norwalk, IA) for $12 \mathrm{~h}$ to create a finer sample for analysis. Total C (TC) and total N (TN) in the litter were quantified using dry combustion methods (Fison NA 15000 Elemental Analyzer, ThermoQuest Corp., Austin, TX). Standing stocks of $\mathrm{C}$ and $\mathrm{N}$ in each litter class $\left(\mathrm{g} \mathrm{m}^{-2}\right)$ were computed using litter $\mathrm{C}$ and $\mathrm{N}$ concentrations, litter mass, and sample area $\left(0.25 \mathrm{~m}^{2}\right)$.

Four $3.2 \mathrm{~cm}$-diam. soil cores were collected within $0.25 \mathrm{~m}$ of each grid point, divided into 0-7.5 and 7.5$15 \mathrm{~cm}$ depth increments, and composited by depth. At the time of sampling, the field east of the shelterbelt was in winter wheat following harvest of soybean and tillage. The field west of the shelterbelt had been

\footnotetext{
${ }^{1}$ Mention of trade names or commercial products in this article is solely for the purpose of providing specific information and does not imply recommendation or endorsement by the U.S. Department of Agriculture.
}

cropped with corn (Zea mays L.) and the stubble remained on the surface after recent harvest of the grain. Surface crop residue was brushed aside before collection of soil cores from the cultivated field grid points.

All soil samples were weighed and a subsample removed and dried at $105^{\circ} \mathrm{C}$ for $24 \mathrm{~h}$ to determine soil water content and bulk density. All remaining fieldmoist samples were passed through a $8-\mathrm{mm}$ sieve, visible roots removed, and a $\sim 100$-g subsample of this sieved soil was passed through a $2-\mathrm{mm}$ sieve. All soil samples were then air-dried. A $\sim 15$-g sample of the air dry $<2 \mathrm{~mm}$-diam. soil was placed on a roller mill for $12 \mathrm{~h}$ to create a fine powder for total $\mathrm{C}$ and $\mathrm{N}$ analysis. TC and TN were measured using dry combustion and soil inorganic carbon (SIC) were quantified using the pressure calcimeter method of Sherrod et al. (2002). Soil organic C (SOC) was calculated as the difference between soil TC and SIC. Samples of air dry, $2 \mathrm{~mm}$ soil were used to determine particle size (hydrometer method, Gee and Or 2002), $\mathrm{pH}$ in water (1:1 paste) $\mathrm{pH}$ in a buffer solution (SMP, Watson and Brown 1998), Bray P (P-1, Frank et al. 1998), and $\mathrm{K}, \mathrm{Ca}, \mathrm{Mg}$, and $\mathrm{Na}$ via ammonium acetate extraction (Warncke and Brown 1998). Estimates of cation exchange capacity (CEC) and exchangeable acidity were obtained from the extractable $\mathrm{K}, \mathrm{Ca}, \mathrm{Mg}$, and $\mathrm{Na}$ data and from SMP buffer pH, respectively (Warncke and Brown 1998). SingleFactor ANOVA and Fisher's Protected LSD were used to test for differences in soil parameters between samples from cultivated $(n=56)$ and uncultivated soil $(n=62)$. ANOVAs were also completed on the litter class data and on 3 litter fractions; Woody 
(sticks, pine needles, pine cones/juniper seeds, and deciduous leaves), Non-woody (annuals and corn residue), and Mixed (worm casts, insect carapaces, coarse and fine duff).

\section{Results and discussion}

Significant differences were observed between soil under the shelterbelt and soil from the cultivated fields for most parameters in both the 0-7.5 and 7.5-15 cm layers (Table 2). For the $0-7.5 \mathrm{~cm}$ layer, SOC concentration was $55 \%$ greater under the shelterbelt than in the cultivated fields (3.04 vs. 1.96\%). SOC under the shelterbelt was also greater when expressed as an areal mass $\left(\mathrm{g} \mathrm{m}^{-2}\right)$ of SOC although, due to significantly lower bulk densities beneath the shelterbelt ( 1.02 vs. $1.27 \mathrm{Mg} \mathrm{m}^{-3}$ ), the difference was only $24 \%\left(2,310\right.$ vs. $\left.1,856 \mathrm{~g} \mathrm{~m}^{-2}\right)$. There were no significant differences for SIC, which accounted for $<0.3 \%$ of the TC. For TN, both concentration and mass were significantly greater under the shelterbelt with again a proportionally smaller difference when expressed on a mass per unit area basis. The difference in $\mathrm{C}: \mathrm{N}$ ratio (calculated as $\% \mathrm{SOC} / \% \mathrm{TN}$ ) was also highly significant with values of 11.9 and 10.6 for the shelterbelt and cultivated fields, respectively.

Amounts of $\mathrm{C}$ and $\mathrm{N}$ parameters were consistently lower in the $7.5-15 \mathrm{~cm}$ layer and had generally smaller differences between the shelterbelt and cultivated fields as compared to the 0-7.5 cm layer. SIC was again a very small $(<0.3 \%)$ component of TC and was not different between the shelterbelt and cultivated fields. Although concentrations of SOC and TN were still significantly greater under the shelterbelt, both parameters were significantly lower than in the cultivated fields on a mass per unit area basis although only at $P<0.05$. For both SOC and

Table 2 Mean values of soil properties for upper $(0-7.5 \mathrm{~cm})$ and lower $(7.5-15 \mathrm{~cm})$ layers in the shelterbelt and cultivated fields

\begin{tabular}{|c|c|c|c|c|}
\hline \multirow[t]{2}{*}{ Soil property } & \multicolumn{2}{|l|}{$0-7.5 \mathrm{~cm}$} & \multicolumn{2}{|l|}{$7.5-15 \mathrm{~cm}$} \\
\hline & Shelterbelt & Fields & Shelterbelt & Fields \\
\hline SOC $(\%)$ & $3.04 * * *$ & $1.96 * * *$ & $1.99 * * *$ & $1.77 * * *$ \\
\hline $\operatorname{SIC}(\%)$ & 0.009 & 0.004 & 0.004 & 0.004 \\
\hline $\mathrm{TC}(\%)$ & $3.04 * * *$ & $1.96 * * *$ & $2.00 * * *$ & $1.78 * * *$ \\
\hline $\operatorname{SOC}\left(\mathrm{g} \mathrm{m}^{-2}\right)$ & $2,310 * * *$ & $1,856^{* * *}$ & $1,684^{*}$ & $1,767^{*}$ \\
\hline $\operatorname{SIC}\left(\mathrm{g} \mathrm{m}^{-2}\right)$ & 7.1 & 4.3 & 3.2 & 3.2 \\
\hline $\mathrm{TC}\left(\mathrm{g} \mathrm{m}^{-2}\right)$ & $2,317 * * *$ & $1,860 * * *$ & $1,687 *$ & $1,770^{*}$ \\
\hline $\mathrm{TN}(\%)$ & $0.254 * * *$ & $0.185 * * *$ & $0.180 * * *$ & $0.167 * * *$ \\
\hline $\mathrm{TN}\left(\mathrm{g} \mathrm{m}^{-2}\right)$ & $194 * *$ & $176^{* *}$ & $152 * * *$ & $166^{* * *}$ \\
\hline $\mathrm{C}: \mathrm{N}$ & $11.9 * * *$ & $10.6^{* * *}$ & $11.1 * * *$ & $10.7 * * *$ \\
\hline Bulk density $\left(\mathrm{Mg} \mathrm{m}^{-3}\right)$ & $1.02 * * *$ & $1.27 * * *$ & $1.13^{* * *}$ & $1.34 * * *$ \\
\hline Sand $(\%)$ & $19.4^{*}$ & $17.9^{*}$ & $18.0 * *$ & $16.7 * *$ \\
\hline Silt (\%) & $44.0 * * *$ & $46.7 * * *$ & $44.7 * * *$ & $46.7 * * *$ \\
\hline Clay $(\%)$ & $36.6 * *$ & $35.4 * *$ & $37.3^{*}$ & $36.6^{*}$ \\
\hline CEC $\left(\mathrm{cmol} \mathrm{kg}{ }^{-1}\right)$ & $19.3 * *$ & $17.4 * *$ & 16.3 & 16.8 \\
\hline $\mathrm{pH}$ (water) & $6.1 * *$ & $6.4 * *$ & $5.5 * * *$ & $6.1 * * *$ \\
\hline pH (SMP buffer) & $6.7 * *$ & $6.9 * *$ & $6.4 * * *$ & $6.7 * * *$ \\
\hline Exch. acidity (meq $100 \mathrm{~g}^{-1}$ ) & $3.61 * *$ & $1.96^{* *}$ & $6.60 * * *$ & $3.96^{* * *}$ \\
\hline Phosphorus $\left(\mu \mathrm{g} \mathrm{g}^{-1}\right)$ & $7.9 * * *$ & $11.7 * * *$ & $3.3 * * *$ & $6.7 * * *$ \\
\hline Potassium $\left(\mu \mathrm{g} \mathrm{g}^{-1}\right)$ & 58.5 & 62.0 & 52.2 & 50.4 \\
\hline Calcium $\left(\mu \mathrm{g} \mathrm{g}^{-1}\right)$ & $277 * *$ & $246 * *$ & $220 *$ & $238^{*}$ \\
\hline Magnesium $\left(\mu \mathrm{g} \mathrm{g}^{-1}\right)$ & $42.9 * *$ & $37.3^{* *}$ & $43.3^{* *}$ & $39.2 * *$ \\
\hline Sodium $\left(\mu \mathrm{g} \mathrm{g}^{-1}\right)$ & 8.8 & 8.9 & $8.8 * *$ & $9.6^{* *}$ \\
\hline
\end{tabular}

Means for samples from shelterbelt and fields from the same depth followed by $*$, **, or *** indicate significant differences at the $0.05,0.01$, and 0.001 probability level as determined by the Fisher's Protected LSD 
$\mathrm{TN}$, differences in concentration were statistically highly significant although absolute differences were much smaller than for the $0-7.5 \mathrm{~cm}$ layer. However, due to the large difference in bulk density between the shelterbelt and fields $\left(1.13\right.$ vs. $\left.1.34 \mathrm{Mg} \mathrm{m}^{-3}\right)$, the areal masses of SOC and $\mathrm{TN}$ were greater in the cultivated fields, although only by a relatively small percentage $(4.9 \%$ and $9.2 \%)$. The small differences between the 0-7.5 and 7.5-15 cm layers for SOC, $\mathrm{TN}$, and $\mathrm{C}: \mathrm{N}$ in the cultivated areas are likely due to mixing of the soil during tillage operations. Patterns of SOC and TN on a mass per unit area basis and C:N with distance across the shelterbelt graphically illustrate the spatial relationship between cultivation, tree rows, and soil parameters (Fig. 1). Greater SOC and $\mathrm{TN}$ and elevated $\mathrm{C}: \mathrm{N}$ especially in the $0-7.5 \mathrm{~cm}$ layer within the shelterbelt are clearly evident. Even though the field west of the shelterbelt was under organic crop production from 1996 to 2000 and received cattle manure applications in 1997, 1998, 2000, and 2003, neither SOC nor TN in the west field were significantly greater than in the east field, which remained under conventional crop management.

To aid in interpretation of the tree litter input, the litter classes were grouped into 3 litter fractions; (1) Woody (sticks, pine needles, pinecones/juniper seeds, and deciduous leaves), (2) Non-woody (annuals and corn residue), and Mixed (worm casts, insect carapaces, and coarse and fine duff). Total litter mass varied from $\sim 1,000 \mathrm{~g} \mathrm{~m}^{-2}$ to $8,000 \mathrm{~g} \mathrm{~m}^{-2}$ with the least amount of litter near the shelterbelt margins and the greatest amount just east of the eastern tree row (Fig. 2). Less litter $\left(\sim 4,000 \mathrm{~g} \mathrm{~m}^{-2}\right)$ between the tree rows may be due to significant natural pruning as there were no live branches near the ground between the tree rows. Fewer live branches would result in
Fig. 1 Mean values by position across shelterbelt of soil organic carbon (SOC), total nitrogen (TN) and $\mathrm{C}: \mathrm{N}$ for $0-0.7 .5$ (closed squares) and $7.5-15 \mathrm{~cm}$ (open squares) layers. Tree symbols indicate position of tree rows and arrows indicate extent of uncultivated area. Error bars are standard deviations
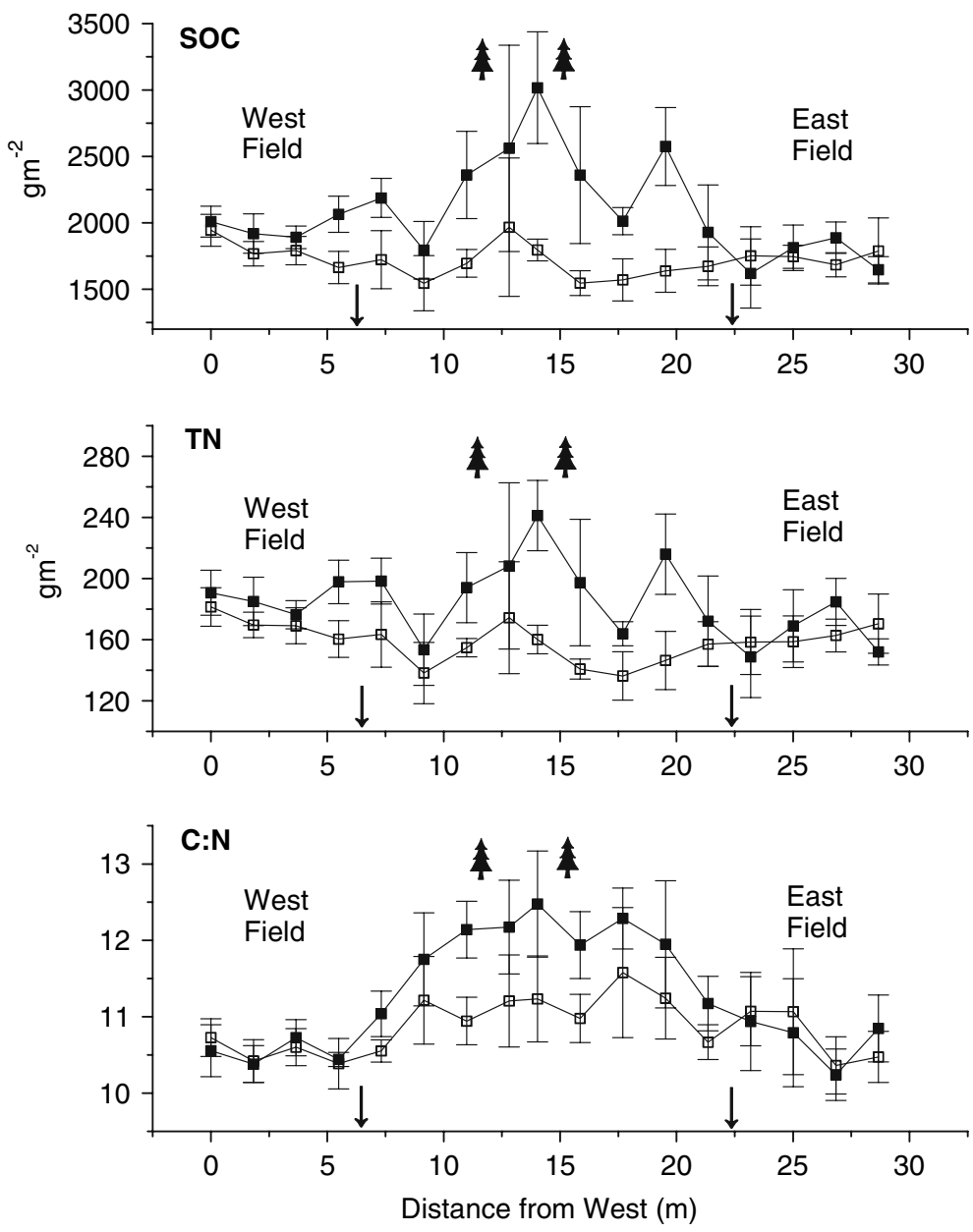
Fig. 2 Total litter mass by position across shelterbelt. Woody litter includes sticks, pine needles, pine cones/juniper seeds, and deciduous leaves, nonwoody litter includes annuals and corn residue, and mixed litter includes worm casts, insect carapaces, and coarse and fine duff. Tree symbols indicate position of tree rows

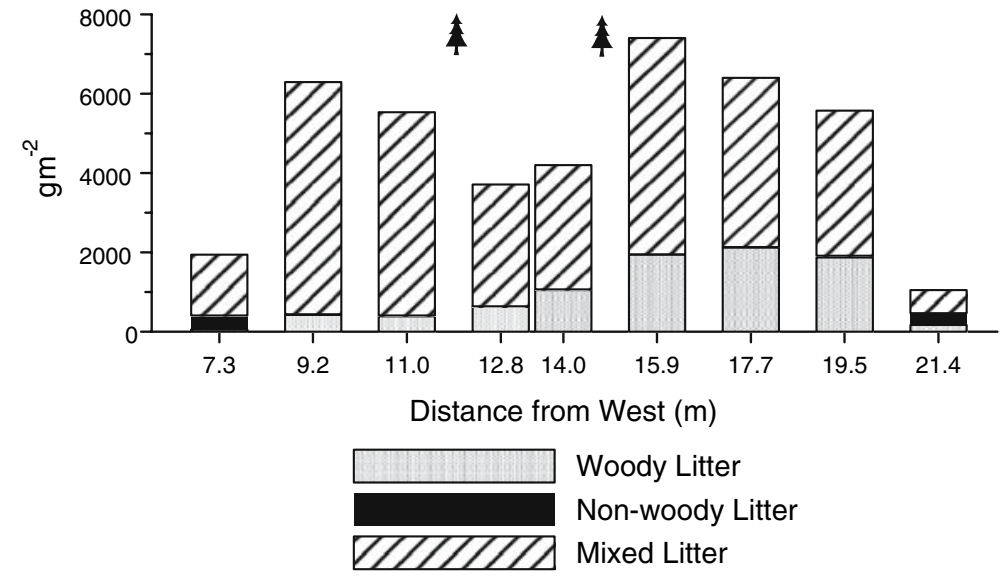

lower organic inputs through annual needle/leaf turnover. Overall, $>77 \%$ of the litter mass was in the Mixed fraction with increasing amounts of Woody litter from west to east (average $21 \%$ of total) and significant amounts of Non-woody litter only at the shelterbelt margins. Greater amounts of litter just outside the tree rows suggest that these areas had more live branches and greater annual inputs from needle/leaf turnover. Greater litter on the eastern side of the shelterbelt may also be due to microclimate effects on plant growth as the western side of the shelterbelt received full sun during the afternoon. Less natural regeneration was noted for this side of the shelterbelt, perhaps due to hotter, drier conditions. Prevailing westerly winds may have caused some litter redistribution as well.

Within the litter fractions, the coarse and fine duff classes accounted for $92 \%$ of the mass of the Mixed litter fraction (Table 3). The fine duff class contained an appreciable amount of soil. A sub-sample of each fine duff sample was ashed in a muffle furnace to determine the mineral content. The average mineral content in the fine duff was $54.4 \pm 10.2 \%$. If this mineral component is subtracted from the fine duff class, this class still had the greatest mass $\left(1,418 \mathrm{~g} \mathrm{~m}^{-2}\right)$ and the average total litter mass was reduced by $30 \%$ to $3,248 \mathrm{~g} \mathrm{~m}^{-2}$. Some of this soil was likely collected with the litter as the boundary between litter layer and soil surface was sometimes uneven and diffuse. Other possible sources of soil in the litter include incorporation via soil arthropods and deposition of sediment deposited by wind or water. The organic component of the fine duff class included the scale-like leaves of the red cedar, which were too numerous to be sorted by visual identification, and small fragments of the other litter classes. Sticks and pine cones/juniper seeds comprised $88 \%$ of the mass of the Woody fraction while annuals comprised $88 \%$ of the Non-woody fraction. Overall, the greatest mass of litter was found in fine and coarse duff classes followed by sticks, pine cones/juniper seeds, and worm casts.

The Mixed litter fraction also had a significantly greater mass of TC and TN, representing $62 \%$ and $76 \%$ of the TC and TN, respectively (Table 3). Sticks and pine cones/juniper seeds again made intermediate contributions to TC and TN mass with the other litter classes making minor contributions. The Mixed fraction had the lowest \% TC however, as the coarse and fine duff classes had average TC of $28.3 \%$ and $22.0 \%$, which were significantly lower than all other classes except worm casts $(8.6 \%)$. The Woody fraction had significantly greater $\%$ TC with pine needles, sticks, and pine cones/juniper seeds all having $\mathrm{TC}>45 \%$. The Mixed fraction had the greatest $\% \mathrm{TN}$ but also contained the litter classes with the greatest (insect carapaces, 2.29\%) and lowest (worm casts, $0.63 \%$ ) concentrations. All other litter classes ranged from $1.06 \%$ to $1.37 \% \mathrm{TN}$. Due to the significantly lower TC in the Mixed fraction, this fraction also had the lowest $\mathrm{C}: \mathrm{N}$ ratio averaging 20.6 compared to 37.6 and 39.8 for the Woody and Nonwoody fractions. The sticks, annuals, and pine needle classes all had C:N >40. However, the Non-woody fraction contributed $<2 \%$ of the litter mass so the primary contribution of high C:N litter was by the Woody fraction $(20.8 \%$ of mass with an average C:N of 37.6). 
Table 3 Mean values of total dry mass, TC and TN mass and concentration, and C:N ratio by litter class and fraction for litter samples collected beneath the shelterbelt

\begin{tabular}{lcccccc}
\hline Litter class & Mass $\left(\mathrm{g} \mathrm{m}^{-2}\right)$ & $\mathrm{TC}\left(\mathrm{g} \mathrm{m}^{-2}\right)$ & $\mathrm{TN}\left(\mathrm{g} \mathrm{m}^{-2}\right)$ & $\mathrm{TC}(\%)$ & $\mathrm{TN}(\%)$ & $\mathrm{C}: \mathrm{N}$ \\
\hline 1. Sticks & $497.0 \mathrm{c}$ & $231.6 \mathrm{~b}$ & $4.9 \mathrm{c}$ & $45.5 \mathrm{~b}$ & $1.06 \mathrm{e}$ & $44.5 \mathrm{a}$ \\
2. Pine needles & $91.2 \mathrm{e}$ & $45.2 \mathrm{~d}$ & $1.2 \mathrm{~d}$ & $49.2 \mathrm{a}$ & $1.26 \mathrm{bcd}$ & $40.0 \mathrm{~b}$ \\
3. Pine cones/jun. seeds & $363.0 \mathrm{~d}$ & $165.8 \mathrm{c}$ & $5.3 \mathrm{c}$ & $45.2 \mathrm{~b}$ & $1.36 \mathrm{bc}$ & $34.8 \mathrm{c}$ \\
4. Deciduous leaves & $21.2 \mathrm{fg}$ & $8.6 \mathrm{~g}$ & $0.30 \mathrm{e}$ & $40.6 \mathrm{~d}$ & $1.37 \mathrm{~b}$ & $31.1 \mathrm{c}$ \\
5. Annuals & $76.0 \mathrm{f}$ & $32.6 \mathrm{ef}$ & $0.86 \mathrm{e}$ & $44.0 \mathrm{c}$ & $1.13 \mathrm{de}$ & $41.2 \mathrm{~b}$ \\
6. Corn residue & $10.9 \mathrm{~g}$ & $4.4 \mathrm{~g}$ & $0.10 \mathrm{f}$ & $40.8 \mathrm{~d}$ & $1.20 \mathrm{de}$ & $39.7 \mathrm{~b}$ \\
7. Worm casts & $267.1 \mathrm{~d}$ & $23.1 \mathrm{de}$ & $1.7 \mathrm{~d}$ & $8.6 \mathrm{~g}$ & $0.63 \mathrm{f}$ & $13.6 \mathrm{f}$ \\
8. Insect carapaces & $9.3 \mathrm{~g}$ & $3.7 \mathrm{~g}$ & $0.22 \mathrm{ef}$ & $41.4 \mathrm{~d}$ & $2.29 \mathrm{a}$ & $26.9 \mathrm{~d}$ \\
9. Coarse duff & $723.1 \mathrm{~b}$ & $202.6 \mathrm{~b}$ & $8.6 \mathrm{~b}$ & $28.3 \mathrm{e}$ & $1.21 \mathrm{bcd}$ & $23.6 \mathrm{~d}$ \\
10. Fine duff & $2607.0 \mathrm{a}$ & $573.5 \mathrm{a}$ & $31.4 \mathrm{a}$ & $22.0 \mathrm{f}$ & $1.20 \mathrm{de}$ & $18.2 \mathrm{e}$ \\
Litter fractions & & & & & \\
Woody (1-4) & $972.3 \mathrm{~b}$ & $451.2 \mathrm{~b}$ & $11.7 \mathrm{~b}$ & $45.1 \mathrm{a}$ & $1.26 \mathrm{a}$ & $37.6 \mathrm{a}$ \\
Non-woody (5-6) & $86.8 \mathrm{c}$ & $37.0 \mathrm{c}$ & $1.0 \mathrm{c}$ & $42.3 \mathrm{~b}$ & $1.18 \mathrm{~b}$ & $39.8 \mathrm{a}$ \\
Mixed (7-10) & $3606.4 \mathrm{a}$ & $803.0 \mathrm{a}$ & $41.8 \mathrm{a}$ & $25.0 \mathrm{c}$ & $1.33 \mathrm{a}$ & $20.6 \mathrm{~b}$ \\
Overall sum/average & 4665.5 & 1291.2 & 54.5 & 36.4 & 1.27 & 31.2 \\
\hline
\end{tabular}

Means followed by the same letter within columns for individual litter fraction and fraction classes were not significantly different as determined by the Fisher's Protected LSD $(P<0.05)$

Figure 3 presents the sum of SOC and TN and the average $\mathrm{C}: \mathrm{N}$ by position for both soil layers (i.e. 0 $15 \mathrm{~cm}$ ) and the average TC, TN, and C:N for all litter and for the 3 litter fractions. Carbon in the SOC of the surface $15 \mathrm{~cm}$ beneath the shelterbelt was greater than the $\mathrm{C}$ contained in the litter (TC) by a factor of $\sim 3\left(3,994\right.$ vs. $\left.1,291 \mathrm{~g} \mathrm{~m}^{-2}\right)$. TC in the litter generally increased from west to east following the pattern observed for litter mass (Fig. 2) with the peak litter TC coinciding with a downtrend in SOC. Conversely, the maximum SOC between the tree rows coincides with an area of relatively low litter TC. These observations may indicate lower input and/or more rapid decomposition of litter and incorporation into SOC between the tree rows and/or greater input and slower degradation of litter outside the tree rows. Similar spatial relationships were observed for TN, although average soil TN exceeded average litter TN by a factor of over 6 (346 vs. $54.5 \mathrm{~g} \mathrm{~m}^{-2}$ ). Litter C:N averaged 31.2 , which was nearly three times greater than for the soil beneath the shelterbelt (11.5). Aside from Non-woody litter at one location between the tree rows, there was a general small reduction in litter $\mathrm{C}: \mathrm{N}$ from west to east with an increase just at the eastern shelterbelt boundary.

Greater SOC and TN in the shelterbelt soil are attributed to several factors including absence of disturbance by tillage, increased organic inputs by tree litter, reduction of surface soil loss by wind and water erosion, and deposition of wind-blown sediment. The area between and adjacent to the tree rows would have been uncultivated since shortly after planting of the trees. The width of the uncultivated area outside the tree rows would have slowly increased over time as the trees grew and extended their branches. Numerous studies of tillage effects on SOC have consistently shown a strong positive relationship between lack of soil disturbance and greater SOC (Kern and Johnson 1993; Dick et al. 1998; West and Post 2002). The areas just outside the tree rows had some of the thickest litter layers. The margin areas closer to the cultivated fields had progressively thinner litter layers and had a mixed understory of perennial grasses, small trees, and shrubs. Shelterbelts are designed to reduce wind speed thereby reducing entrainment of soil particles in their lee but also settling out any sediment already in the air (van Eimern 1964; Plate 1971; Gupta et al. 1983). The presence of permanent ground cover would also have reduced soil detachment by raindrop impact and improved trapping of sediment in surface runoff.

Soil physical and chemical properties were analyzed to characterize afforestation effects on soil 
Fig. 3 Mean values by position across shelterbelt of soil organic carbon (SOC) and total carbon (TC), total nitrogen (TN) and C:N for soil $(0-15 \mathrm{~cm})$ and tree litter. Tree symbols indicate position of tree rows and arrows indicate extent of uncultivated area. Error bars are standard deviations
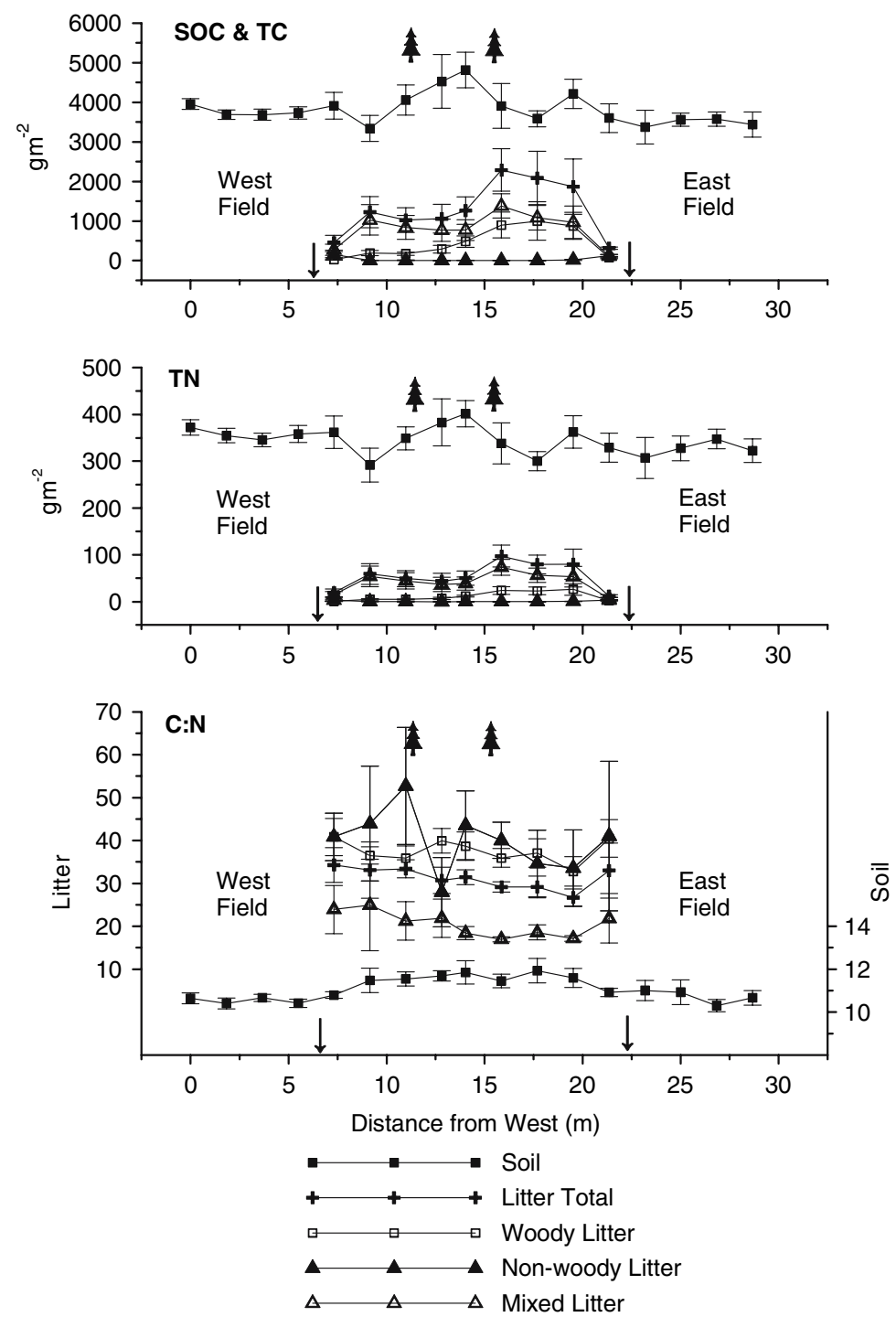

properties and perhaps elucidate which of the above processes may have affected the observed patterns of SOC. Bulk density and silt content were consistently lower while sand and clay content were greater in the soil beneath the shelterbelt (Table 2, Fig. 4). The $\sim 20 \%$ average reduction in bulk density beneath the shelterbelt is most striking and, as already discussed, had important implications when expressing SOC and $\mathrm{TN}$ on a mass per unit area basis. Lower bulk density beneath the trees would be expected as there had been no compaction by farm machinery for over three decades and natural ameliorization would occur due to soil arthropod activity and with fine roots exploring and decaying in the surface soil layers. The marked increase in silt and decrease in clay in the east field suggests deposition of wind blown silt on the leeward side of the shelterbelt. Silt content for both soil layers averaged $44.4 \%, 44.4 \%$, and $48.8 \%$ in the west field, under the shelterbelt, and in the east field, respectively. Clay contents for the same locations were $38.0 \%, 37.0 \%$, and $34.1 \%$. This interpretation, while consistent with accepted theory, would require further testing to verify, perhaps using analysis of ${ }^{137} \mathrm{Cs}$ content in the soil profile to determine if significant wind-blown sediment deposition had occurred (Ritchie and McHenry 1990).

Soil beneath the shelterbelt had lower $\mathrm{pH}$ and greater exchangeable acidity (Table 2, Fig. 5). 
Fig. 4 Mean values by position across shelterbelt of bulk density and sand, silt, and clay content for 0 0.7 .5 (closed squares) and $7.5-15 \mathrm{~cm}$ (open squares) layers. Tree symbols indicate position of tree rows and arrows indicate extent of uncultivated area. Error bars are standard deviations
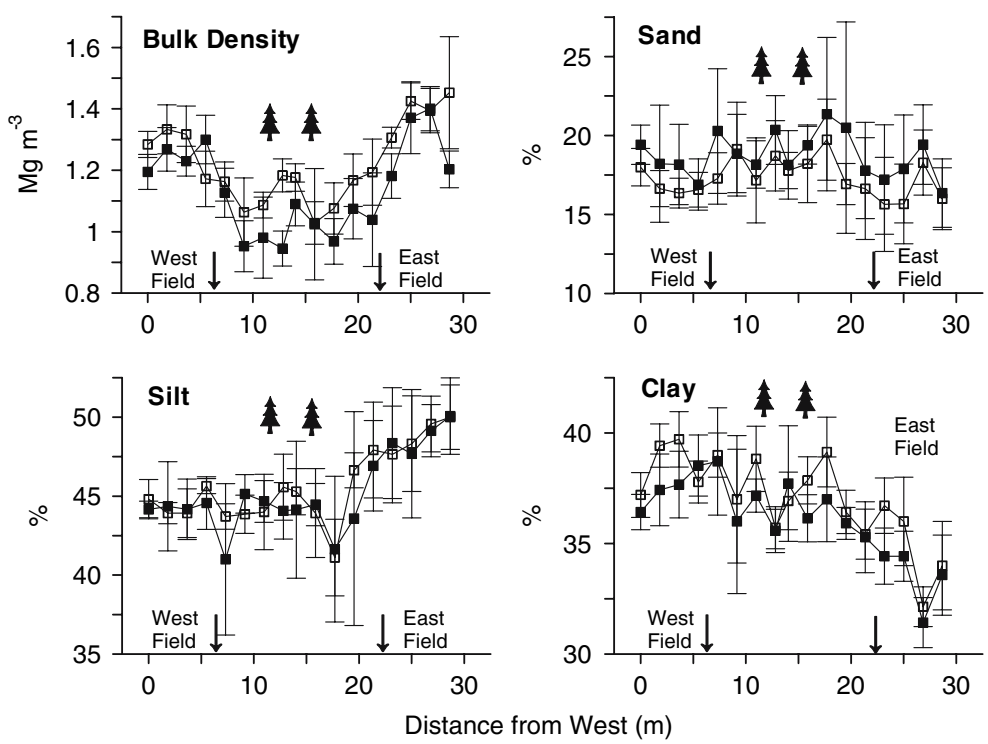

Although the average differences in $\mathrm{pH}$ were small (0.2-0.6 units), they were consistent and significant at $P<0.05$ or 0.01 . There was extreme variation in $\mathrm{pH}$ within the shelterbelt as, for instance, $\mathrm{pH}$ in water for the $0-7.5 \mathrm{~cm}$ layer had a range of 3 units (4.3-7.3) compared to only 1.2 units in the cultivated fields (5.9-7.1). Soil $\mathrm{pH}$ in water for both layers decreased sharply ( $\sim 2$ units) just outside the tree rows from approximately $6.5-4.5$ and $\sim 1$ unit from approximately 7-6 when measured in the SMP buffer solution. The west field had a slightly higher $\mathrm{pH}$ values (0.1-0.9 units) for both solutions and depths compared to the east field, perhaps a result of multiple manure applications (instead of nitrogen fertilizers) and a recent aglime application in 1997.

The introduction of pine species is often assumed to acidify the soil (Coile 1933; Millar 1974; Sariyildiz et al. 2005) while eastern red cedar has been found to raise the soil pH (Coile 1933; Spurr 1940; Read and Walker 1950). In this study, it is clear that
Fig. 5 Mean values by position across shelterbelt of cation exchange capacity (CEC), $\mathrm{pH}$ in water (1:1), exchangeable acidity, and $\mathrm{pH}$ in SMP buffer solution for 0-0.7.5 (closed squares) and 7.5-15 cm (open squares) layers. Tree symbols indicate position of tree rows and arrows indicate extent of uncultivated area. Error bars are standard deviations
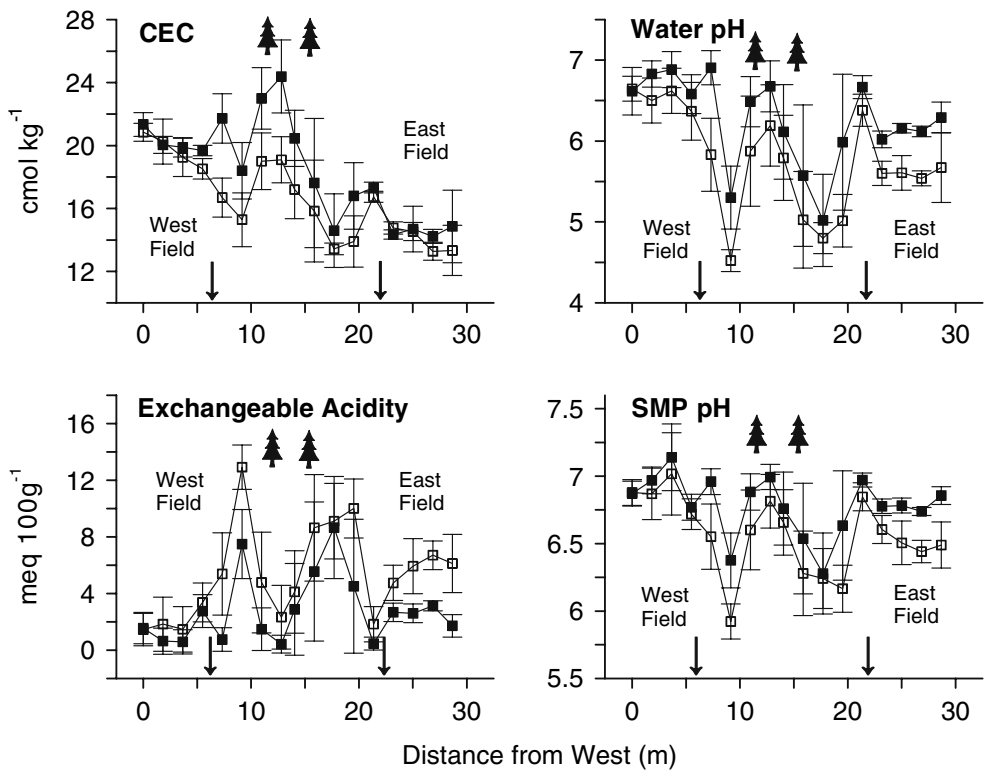
Fig. 6 Mean values by position across shelterbelt of nutrient concentrations for $0-0.7 .5$ (closed squares) and $7.5-15 \mathrm{~cm}$ (open squares) layers. Tree symbols indicate position of tree rows and arrows indicate extent of uncultivated area. Error bars are standard deviations
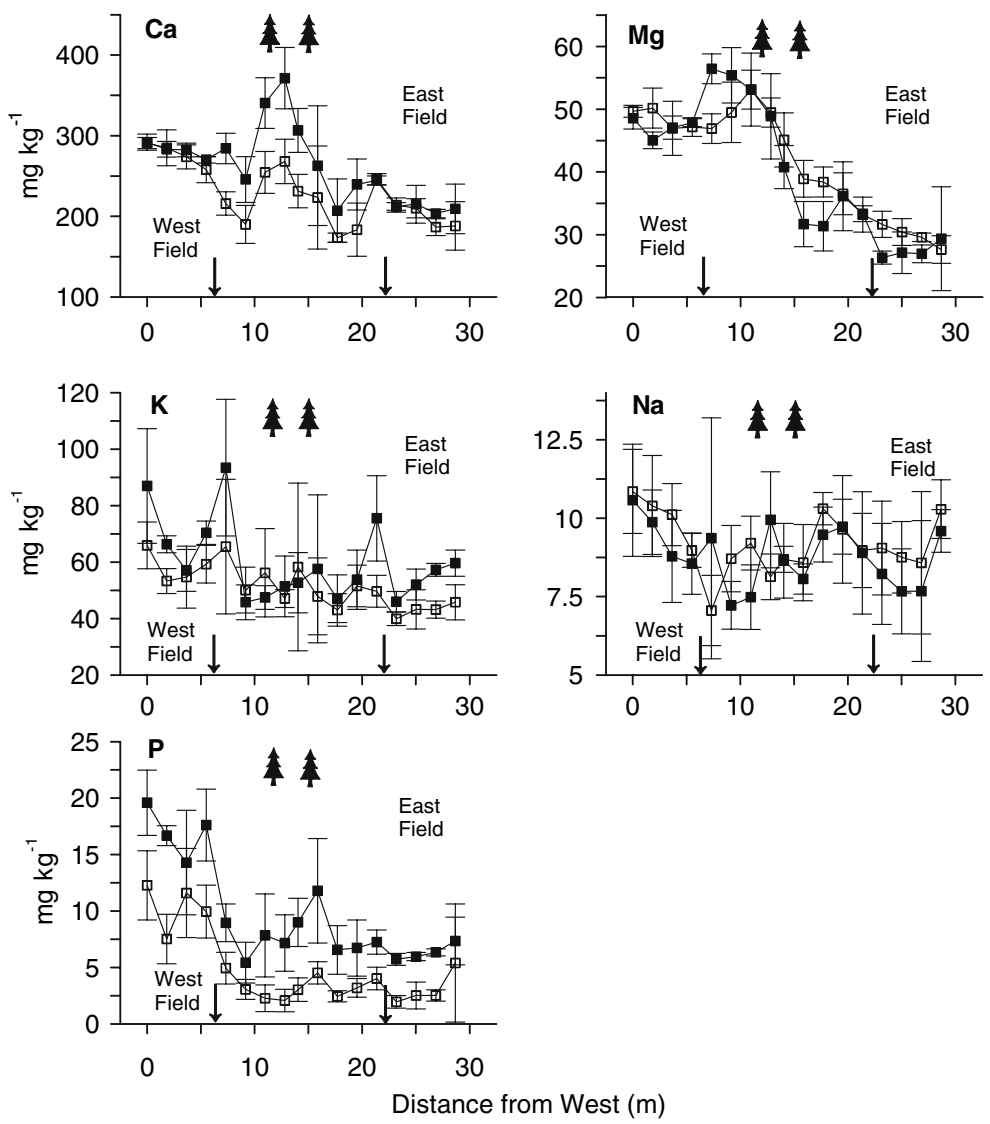

soil acidification is occurring in localized areas within the shelterbelt suggesting that the effects of the scotch pine on soil $\mathrm{pH}$ is dominant at these locations (just outside the tree rows). These same locations have high exchangeable acidity and low CEC compared to other areas within the shelterbelt. The CEC also shows a general pattern of decreasing values from west to east, which is consistent with the pattern of soil clay content.

Within the shelterbelt, areas of low $\mathrm{pH}$ coincided with areas of low SOC and TN and greater litter mass (Figs. 2, 3, 5). These results suggest that low soil $\mathrm{pH}$ may be inhibiting litter decomposition and the incorporation of litter C into SOC. Williams (1972) observed increased rates of decomposition of scotch pine humus at higher $\mathrm{pH}$ following lime application. In general, tree litter decomposition rates are most affected by litter quality, soil temperature, and soil moisture conditions (Millar 1974; Berg 1986; Facelli and Pickett 1991). Although the C:N ratio is traditionally considered a critical indicator of potential decomposition rate and a determinant of whether immobilization or mineralization of $\mathrm{C}$ occurs, lignin and cellulose concentrations are also important factors (Millar 1974; Berg et al. 1982). Berg (1986) reported that lignin concentration in scotch pine needle litter was affected by site fertility with measured concentrations of $24 \%$ and $27 \%$ lignin at nutrient-poor and nutrient-rich sites, respectively. Thus, for the Mead shelterbelt, appreciable amounts of sticks, pine needles, and pine cones/juniper seeds with relatively high $\mathrm{C}: \mathrm{N}$ and perhaps elevated lignin content in the needles appear to be accumulating under a productive tree canopy with high soil fertility (compared to typical forest soils) and reduced soil $\mathrm{pH}$.

Although there were no significant differences between the shelterbelt and cultivated fields for $\mathrm{K}$ and only small differences for $\mathrm{Na}$, distinct differences and spatial patterns were observed for $\mathrm{Ca}$ and especially for $\mathrm{Mg}$ and $\mathrm{P}$ (Table 2, Fig. 6). Eastern red cedar leaves are known to have very high concentrations of Ca (Read and Walker 1950; Millar 1974), which may explain the high soil $\mathrm{Ca}$ concentration in the 0-7.5 cm layer beneath the shelterbelt. Although on 
average $\mathrm{Mg}$ was significantly lower and $\mathrm{P}$ was significantly greater in the cultivated fields, both $\mathrm{Mg}$ and $\mathrm{P}$ concentrations exhibited dramatic decreases from west to east. In the $0-7.5 \mathrm{~cm}$ layer, $\mathrm{Mg}$ and $\mathrm{P}$ concentrations averaged 47.1 and $17.0 \mathrm{mg} \mathrm{kg}^{-1}$ in the west field and only 27.4 and $6.3 \mathrm{mg} \mathrm{kg}^{-1}$ in the east field. It is likely that the greater concentrations in the west field reflect nutrient inputs from the recent manure applications, although $\mathrm{Mg}$ concentrations are actually greatest in the western margin of the shelterbelt.

\section{Conclusions}

Measured SOC in the top $15 \mathrm{~cm}$ of soil within the shelterbelt and in the adjacent cultivated fields averaged 3,994 and 3,623 $\mathrm{g} \mathrm{m}^{-2}$, respectively. The $371 \mathrm{~g} \mathrm{~m}^{-2}$ greater SOC measured within the shelterbelt was significant and represents an annual accrual of $10.6 \mathrm{~g} \mathrm{~m}^{-2}$ year $^{-1}$ over the life of the shelterbelt. Tree litter on the soil surface contained an additional $\sim 1,300 \mathrm{~g} \mathrm{C} \mathrm{m}^{-2}$. These SOC and litter $\mathrm{C}$ stocks represent 5.4 and $19.4 \mathrm{Mg} \mathrm{C} \mathrm{km}^{-1}$ of shelterbelt, respectively. Clearly, the increase in SOC and $\mathrm{C}$ contained in the tree litter are significant contributors to the overall $\mathrm{C}$ sequestration potential of this shelterbelt. Additional effort is necessary to identify the mechanism(s) responsible for the observed spatial patterns of SOC within and adjacent to the shelterbelt. Ideally, a complete $\mathrm{C}$ stock assessment should be made of this shelterbelt including quantifying the $\mathrm{C}$ stocks in above- and below-ground biomass and in the deeper soil layers. Such a complete dataset is necessary to provide a full accounting of the $\mathrm{C}$ sequestration potential of this system.

Acknowledgements The authors express appreciation to Paul Doi, Shannon Kulisky, Jon Huffaker, Jody Ohmacht and several student workers for assistance with sample collection and litter sorting.

\section{References}

Anderson DW (1987) Pedogenesis in the grassland and adjacent forests of the Great Plains. In: Stewart BA (ed) Advances in soil science, vol 7. Springer-Verlag, New York, pp 53-93

Berg B (1986) Nutrient release from litter and humus in coniferous forest soils-a mini review. Scand J For Res $1: 359-369$
Berg B, Hannus K, Popoff T, Theander O (1982) Changes in organic chemical components of needle litter during decomposition. Long-term decomposition in a Scots pine forest. I. Can J Bot 60:1310-1319

Brandle JR, Wardle TD, Bratton GF (1992) Opportunities to increase tree planting in shelterbelts and the potential impacts on carbon storage and conservation. In: Sampson RN, Hair D (eds) Forest and global change, vol 1: opportunities for increasing forest cover, Ch. 9. American Forests, Washington, DC, pp 157-176

Coile TS (1933) Soil reaction and forest types in the Duke forest. Ecology 14:323-333

Davis MR, Condron LM (2002) Impact of grassland afforestation on soil carbon in New Zealand: a review of pairedsite studies. Aust J Soil Res 40:675-690

Droze WH (1977) Trees, prairies, and people-tree planting in the plains states. Texas Woman's University Press, Denton, TX, $313 \mathrm{pp}$

Dick WA, Blevins RL, Frye WW, Peters SE, Christenson DR, Pierce FJ, Vitosh ML (1998) Impacts of agricultural management practices on $\mathrm{C}$ sequestration in forest-derived soils of the eastern Corn Belt. Soil Tillage Res 47:235-244

Facelli JM, Pickett STA (1991) Plant litter: its dynamics and effects on plant community structure. Bot Rev 57:1-32

Frank K, Beegle D, Denning J (1998) Phosphorus. In: Recommended chemical soil test procedures for the north central region. North Central Regional Research Publ. No. 221 (Revised). Missouri Agricultural Experiment Station, Columbia, MO, pp 21-29

Gale WJ, Cambardella CA (2000) Carbon dynamics of surface residue- and root-derived organic matter under simulated no-till. Soil Sci Soc Am J 64:190-195

Gee GW, Or D (2002) Particle-size analysis. In: Dane JH, Topp GC (eds) Methods of soil analysis-part 4 physical methods. SSSA Book Series No. 5. Soil Science Society of America, Madison, WI, pp 255-293

Gupta JP, Rao GGSN, Gupta GN, Ramana Rao BV (1983) Soil drying and wind erosion as affected by different types of shelterbelts planted in the desert region of Western Rajasthan, India. J Arid Environ 6:53-58

Harmon ME (2001) Carbon sequestration in forests: addressing the scale question. J Forestry 99:24-29

Kern JS, Johnson MG (1993) Conservation tillage impacts on national soil and atmospheric carbon levels. Soil Sci Soc Am J 57:200-210

Kirschbaum MUF (2003) Can trees buy time? An assessment of the role of vegetation sinks as part of the global carbon cycle. Climatic Change 58:47-71

Kort J, Turnock R (1999) Carbon reservoir and biomass in Canadian prairie shelterbelts. Agroforestry Systems 44:175-186

Millar CS (1974) Decomposition of coniferous leaf litter. In: Dickinson CH, Pugh GJF (eds) Biology of plant litter decomposition, vol 1. Academic Press, London, pp 105128

Nair PKR, Nair VD (2003) Carbon storage in North American agroforestry systems. In: Kimble JM et al (eds) The potential of U.S. forest soils to sequester carbon and mitigate the greenhouse effect, Ch. 20. CRC Press, Boca Raton, FL, pp 333-346 
Paul KI, Polglase PJ, Nyakuengama JG, Khanna PK (2002) Change in soil carbon following afforestation. For Ecol Manage 168:241-257

Pettapiece WW (1969) The forest-grassland transition. In: Pawluk S (ed) Pedology and quaternary research. Univ. of Alberta, Edmonton, AB, pp 103-113

Plate EJ (1971) The aerodynamics of shelter belts. Agric Meteorol 8:203-222

Read RA, Walker LC (1950) Influence of eastern redcedar on soil in Connecticut pine plantations. J Forestry 48:337339

Ritchie JC, McHenry JR (1990) Application of radioactive fallout cesium-137 for measuring soil erosion and sediment accumulation rates and patterns: a review. J Environ Qual 19:215-233

Sariyildiz T, Anderson JM, Kucuk M (2005) Effects of tree species and topography on soil chemistry, litter quality, and decomposition in Northeast Turkey. Soil Biol Biochem 37:1695-1706

Schroeder P (1994) Carbon storage benefits of agroforestry systems. Agrofor Syst 27:89-97

Sherrod LA, Dunn G, Peterson GA, Kolberg RL (2002) Inorganic carbon analysis by modified pressure-calcimeter methods. Soil Sci Soc Am J 66:299-305

Spurr SH (1940) The influence of two juniperus species on soil reaction. Soil Sci 50:289-294
Vesterdal L, Ritter E, Gundersen P (2002) Change in soil organic carbon following afforestation of former arable land. For Ecol Manage 169:137-147

Van Eimern J (1964) Windbreaks and shelterbelts. World Meteorol Org Tech Note No. 59, 188 pp

Vitousek PM (1991) Can planted forests counteract increasing atmospheric carbon dioxide? J Environ Qual 20:348-354

Warncke D, Brown JR (1998) Potassium and other basic cations. In: Recommended chemical soil test procedures for the north central region. North Central Regional Research Publ. No. 221 (Revised). Missouri Agricultural Experiment Station, Columbia, MO, pp 31-33

Watson ME, Brown JR (1998) pH and lime requirement. In: Recommended chemical soil test procedures for the north central region. North Central Regional Research Publ. No. 221 (Revised). Missouri Agricultural Experiment Station, Columbia, MO, pp 13-16

West TO, Post WM (2002) Soil organic carbon sequestration rates by tillage and crop rotation: a global data analysis. Soil Sci Soc Am J 66:1930-1946

Williams BL (1972) Nitrogen mineralization and organic matter decomposition in scots pine humus. Forestry 45:177-188 